\title{
KEPEMIMPINAN KIYAI PONDOK PESANTREN
}

\author{
Imas Muslimah \\ Universitas Islam Negeri Sunan Gunung Djati Bandung \\ Email: imasmuslimah38@yahoo.com
}

\begin{abstract}
ABSTRAK
Tulisan ini dilatarbelakangi bahwa pondok pesantren merupakan pendidikan tertua dan sampai saat ini memiliki kepercayaan yang tinggi dari masyarakat sekitar. Pesantren mulai membangun dirinya secara "kualitas (mutu)", seperti halnya pada pola manajemen pondok pesantren tradisional yang perlu sentuhan dalam mengelolanya, supaya dalam proses pembelajaran bisa progres. Dengan adanya kemajuan dalam manajemen diharapkan pondok pesantren mampu mengahsilkan out put yang siap menghadapi tantangan zaman, namun dalam hal ini tak sedikit pondok pesantren yang masih menggunakan pola manjemen pondok pesantren tradisional. Pemegang kendali manajerial di pesantren adalah seorang kiyai, selain sebagai pendidikan atau pengajar. Posisi kepemimpinan kiyai di pesantren lebih menekankan pada aspek kepemilikan saham pesantren dan moralitas serta kedalaman ilmu agama, dan sering mengabaikan aspek manajerial. Kiyai atau pengasuh pondok pesantren merupakan elemen yang sangat esensial bagi suatu pesantren, oleh karenanya, sangat wajar jika pertumbuhannya, pesantren sangat bergantung pada peran seorang kiyai.
\end{abstract}

Kata Kunci: Kepemimpinan, Kiyai, Pondok Pesantren

\section{ABSTRACT}

Based on this writing, that the Islamic boarding school is ancient of education, and during nowadays has highly confidence in around of society. The Islamic boarding school begin to develop itself as quality, such as management pattern in traditional Islamic boarding school, that necessarily a manner to manage, in order to process of learning can be progression. Accompanying the progression in management, the Islamic boarding school hoped be able to produce the output that readily to face in age challenge, nevertheless not a few of boarding school still management pattern traditional boarding school used. The controller of managerial in Islamic boarding school is Kiyai, in addition as educator or teacher. The position of Kiyai in Isamic boarding school more emphasized to the ownership of Islamic boarding school share and morality as well as deepness in theology, and regardless frequently in managerial aspect. Kiyai or educator of boarding school is essentially element for an Islamic boarding school, therefore its fairly, that the Islamic boarding school in growth is dependent of a Kiyai position.

Key Words: Leadership, Kiyai, Boarding School 


\section{PENDAHULUAN}

Pondok Pesantren merupakan suatu lembaga pendidikan agama Islam yang tumbuh serta diakui oleh masyarakat sekitar, dengan sistem asrama yang santri-santrinya menerima pendidikan agama melalui sistem pengajian atau madrasah yang sepenuhnya berada di bawah kedaulatan dan kepemimpinan seorang atau beberapa orang kyai dengan ciri khas yang bersifat kharismatis serta independen dalam segala hal (Djamaludin \& Aly, 1991:99).

Peranan Pondok Pesantren dalam tatanan kehidupan sosial sangat besar khususnya dalam pembentukan kepribadian seseorang. Kepribadian yang dimaksud salah satunya adalah terbentuknya akhlak yang mulia, hal ini disebabkan karena Pondok Pesantren mengajarkan tentang keagamaan. Sebagaimana yang tercantum dalam tridarma Pondok Pesantren. Adapun tridarma Pondok Pesantren yang menyangkut kepada prilaku keagamaan sebagai berikut: 1) Keimanan dan ketakwaan terhadap Tuhan. 2) Pengembangan ilmu yang bermanfaat bagi kehidupan. 3) Pengabdian terhadap keagamaan masyarakat dan negara. Ketiga ini untuk mencapai kepada keyakinan dalam beragamanya seseorang. Sehingga penyebaran pesantren sangat perlu sekali untuk menopang salah satu aspek keagamaan dalam diri manusia (Mahpuddin Noor, 2006:19).

Pesantren Al-Mardhiyatul Islamiyah merupakan pesantren salaf yang didirikan oleh $\mathrm{KH}$. Abdul Jalil di Cileunyi tepatnya di kampung Cibagbagan Desa Cileunyi Kulon Kecamatan Cileunyi Kabupaten Bandung pada hari Rabu 1 Januari 1960, pesantren ini didirikan atas dasar komitmen moral dan tanggung jawab $\mathrm{KH}$. Abdul Jalil untuk menegakkan ajaran Islam. Pondok Pesantren Almardhiyatul Islamiyah merupakan pondok pesantren yang pimpinannnya mengelola pondok pesantren dengan caranya sendiri, dan terbebas dari campur tangan pemerintah. Pondok Pesantren Al-Mardhiyatul Islamiyah telah mengalami tiga kali pergantian kepemimpinan. Saat ini, pengganti dan penerus serta yang mengembangkan kepemimpinan Pondok Pesantren Al-Mardhiyyatul Islamiyyah sekaligus sebagai pengajar utama adalah cucu dari KH. Abd. Jalil, yakni KH. Asep Abdurrahman Hambali yang menggantikan posisi sang ayah, KH. Abdul Qodir Zaelani yang telah wafat pada tahun 2011. Seiring berjalannya waktu, pesantren yang didirikan sejak 57 tahun silam ini masih tetap berdiri dan mendapat kepercayaan masyarakat, santrisantri yang berdatangan setiap tahunnya sehingga tidak pernah sepi atau kekurangan peserta didik, dan tetap menjadi pusat pengajaran Islam, serta berperan dalam bidang dakwah dan menjadi pelopor kegiatan sosial keagamaan masyarakat Cileunyi Kulon. Hal tersebut tidak terlepas dari peran seorang kiyai sebagai pimpinan pesantren yang memiliki kharisma tinggi serta memiliki kemampuan atau keterampilan dalam mengelola dan menjaga pesantren sehingga dapat berkembang dan mendapat kepercayaan penuh dalam masyarakat.

Pondok Pesantren yang dikelola oleh kiyai yang mempunyai kemampuan manajerial yang baik, akan dapat menggerakkan seluruh potensi santri. Menurut Afifuddin \& Sutikno (2008:1), pengelolaan merupakan istilah Indonesia yang sama pengertiannya dengan manajemen. Manajemen bila dipraktikan secara komprehensif dan diterapkan secara konsisten akan memberikan arahan yang jelas, langkah yang teratur dan keberhasilan dan kegagalan dapat 
mudah dievaluasi dengan benar, akurat dan lengkap sehingga dapat dijadikan bahan pembelajaran bagi tindakan selanjutnya (Tim Dosen Administrasi Pendidikan UPI, 2013: 86). Manajemen santri dapat diartikan sebagai usaha pengaturan terhadap santri mulai dari santri tersebut masuk pesantren sampai dengan mereka lulus pesantren. Yang diatur secara langsung adalah segi-segi yang berkenaan dengan santri secara langsung, dan segi-segi lain yang berkaitan dengan santri secara tidak langsung. Pengaturan terhadap segi-segi lain selain santri dimaksud untuk memberika layanan yang sebaik mungkin kepada santri (Burhanudin dkk, 2003:52).

Penelitian ini berangkat dari pemikiran bahwa Pondok Pesantren memerlukan manajemen dan pola kepemimpinan yang baik. Penelitian ini menggunakan pendekatan kualitatif dengan metode deskriptif. Tenik pengumpulan data dengan cara observasi partisipasi, wawancara, dan studi dokumentasi. Analisis data dengan unitisasi data, kategorisasi, penafsiran, dan teknik uji keabsahan data dilakukan dengan perpanjangan keikutsertaan, analisis kasus negatif, kecukupan referensi, urai rinci, dan ketekunan pengamatan oleh peneliti dan pihak Pondok Pesantren Al-Mardhiyatul Islamiyah.

\section{Metodologi}

Penelitian ini merupakan penelitian kualitatif dengan metode deskriptif, pengumpulan data dilakukan dengan wawancara, observasi dan studi dokumentasi. Analisis data dilakukan dengan utinitasi data, kategorisasi data, dan penafsiran data. Adapun uji keabsahan data dilakukan dengan ketekunan pengamatan, cek teman sejawat, analisis kasus negative, kecukupan referensi, pengecekan anggota, uraian rinci dan auditing. Dalam langkah penelitian ini dijelaskan tahapan langkah yang dilakukan dalam proses penelitian yang meliputi (1) jenis data (2) sumber data (3) metode dan teknik pengumpulan data (4) langkah analisis data, dan (5) teknik pengumpulan uji abash data (Lexi J Moleong, 2007:224).

\section{PEMBAHASAN}

Menurut Badrudin (2013:1-5), Para ahli memandang manajemen dari sudut yang berbeda yaitu beberapa ahli memandang manajemen sebagai suatu ilmu dan seni, ahli lain memandang manajemen sebagi suatu proses dan sebagai profesi.

1. Manajemen Sebagai IImu dan Seni

Manajemen adalah ilmu dan seni mengatur proses pemanfaatan sumber daya manusia secara efektif, yang didukung oleh sumber-sumber lain dalam organsisasi untuk mencapai tujuan tertentu (Malayu S.P Hasibuan, 2006:2). Menurut Lawrence A. Appley dan Oey Liang Lee menjelaskan bahwa sebagai seni dan ilmu, dalam manajemen terdapat strategi memanfaatkan tenaga dan pikiran orang lain untuk melaksanakan aktivitas yang diarahkan pada pencapaian tujuan yang telah ditentukan sebelumnya (Saefullah, 2012:3).

2. Manajemen Sebagai Proses

Menurut George R. Terry, manajemen merupakan sebuah proses yang khas, yang terdiri dari tindakan-tindakan: Perencanaan, pengorganisasian, menggerakan, dan pengawasan, yang dilakukan untuk menentukan serta 
mencapai sasaran-sasaran yang telah ditetapkan melalui pemanfaatan sumber daya manusia serta sumber-sumber lain (Malayu S.P. Hasibuan, 2006:2). Manajemen Sebagai Profesi.

Profesi adalah suatu pekerjaan yang menuntun persyaratan tertentu yang menghendaki sebagai kompetensi sebagai dasar keahlian khusus, diakui dan dihargai oleh masyarakat, pemerintah, serta memiliki kode etik tertentu. Demikian halnya dengan manajemen sebagai suatu profesi dituntut persyaratan tertentu. Menurut Robert L. Katz seorang profesional harus mempunyai kemampuan/kompetensi, konseptual, sosial, dan tekhnikal. (Badrudin, 2013:5).

Dari pengertian di atas, dapat disimpulkan bahwa manajemen adalah suatu usaha yang dilakukan oleh seseorang atau sekelompok orang yang memiliki keahlian tertentu, agar tercapainya suatu tujuan dalam sebuah organsisasi, dengan cara mengatur proses pemanfaatan sumber daya manusia dan sumber daya lainnya secara efektif dan efisien.

Dalam pandangan Islam, manajemen dipandang sebagai perwujudan amal shaleh yang harus bertitik tolak dari niat baik. Niat baik tersebut akan memunculkan motivasi aktivitas untuk mencapai hasil yang optimal demi kesejahteraan bersama (Saefullah, dkk, 2012:49).

Oteng Sutisna mengemukakan bahwa kepemimpinan merupakan kemampuan mengambil inisiatif dalam situasi social untuk menciptakan bentuk dan prosedur baru, merancang dan mengatur perbuatan, dan dengan berbuat begitu membangkitkan kerja sama kearah tercapainya tujuan. Kepemimpinan juga merupakan setiap perbatan yang dilakukan oleh individu atau kelompok untuk mengkoordinasi dan memberi arah arah kepada individu atau kelompok yang tergabung di dalam wadah tertentu untuk mencapai tujuan yang telah ditetapkan sebelumnya, (Sudarwan Danim, 2010: 6). Kepemimpinan merupakan pelaksanaan dari keterampilan mengelola orang lain sebagai bawahannya, mengelola sumber daya manusia dan sumber daya organisasi secara umum. Hikmat mengatakan bahwa setiap pemimpin harus memiliki managerial skill yang sangat berpengaruh pada kekuasaan yang dimilikinya. Keahlian utama dari kepemimpinan adalah terampil mengendalikan situasi dan kondisi organisasi, yaitu dengan menentukan konsep masa depan organisasi dalam bentuk kerangka kerja visioner (Hikmat,2011:250).

Pemegang kendali manajerial di pesantren adalah seorang kyai, selain sebagai pendidik atau pengajar. Muhammad Tholchah Hasan, (1997:20) melihat kiyai dari empat sisi yakni kepemimpinan ilmiah, spiritualitas, sosial, dan administrasi. Jadi ada beberapa kemampuan yang mestinya terpadu pada pribadi kiyai dalam kapasitasnya sebagai pengasuh dan pembimbing santri. Kiyai atau pengasuh pondok pesantren merupakan elemen yang sangat esensial bagi suatu pesantren. Di samping itu kiyai pondok pesantren biasanya juga sekaligus sebagai penggagas dan pendiri dari pesantren yang bersangkutan. Oleh karenanya, sangat wajar jika pertumbuhannya, pesantren sangat bergantung pada peran seorang kiyai (Amin Haedari, 2005:28).

\section{Kepemimpinan Kiyai di Pondok Pesantren Al-Mardhiyatul Islamiyah}

Pesantren Al-Mardhiyatul Islamiyah merupakan pesantren salaf yang didirikan oleh $\mathrm{KH}$. Abdul Jalil di Cileunyi. Saat ini, pengganti dan penerus serta yang mengembangkan kepemimpinan Pondok Pesantren Al-Mardhiyyatul 
Islamiyyah sekaligus sebagai pengajar utama adalah cucu dari KH. Abd. Jalil, yakni $\mathrm{KH}$. Asep Abdurrahman Hambali yang menggantikan posisi sang ayah, $\mathrm{KH}$. Abdul Qodir Zaelani yang telah wafat pada tahun 2011, dengan harapan agar Pondok Pesantren Al-Mardhiyatul Islamiyah menjadi pusat pengajaran Islam, juga berperan dalam bidang dakwah dan menjadi pelopor kegiatan sosial keagamaan masyarakat Cileunyi Kulon.

Pondok Pesantren Al-Mardhiyatul Islamiyah Cileunyi Kab. Bandung, memiliki sebuah konsep kepemimpinan yang dikembangkan, yaitu konsep kepemimpinan profetik yang mengacu pada wahyu Allah dalam Al Qur'an tentang etos dan sifat kepemimpinan nabi dan rasul. Konsep kepemimpinan itu bukan hanya sesuai dengan syariat Islam namun juga sesuai dengan kebutuhan sosok pemimpin bangsa Indoensia. Kepemimpinan profetik ini memiliki tiga misi berdasarkan misi kepemimpinan Rasulullah SAW. antara lain:

1) Ta'murunabil ma'ruf (menyeru pada kebaikan)

2) Tanhauna 'anil munkar (mencegah kemungkaran)

3) Tu'minunabillah (beriman kepada Allah)

$\mathrm{KH}$. Asep Abdurrahman Hambali sebagai pemimpin melaksanaan Fungsi Managerial, yaitu berupa kegiatan pokok meliputi pelaksanaan:

1) Penyusunan Rencana

2) Penyusunan Organisasi

3) Pengarahan Organisasi

4) Pengendalian Penilaian

5) Pelaporan

Fungsi kepemimpinan berhubungan langsung dengan situasi sosial dalam kehidupan kelompok/organisasi masing-masing, yang mengisyaratkan bahwa setiap pemimpin berada di dalam dan bukan di luar situasi itu.

Mengenai komunikasi dengan bawahan, $\mathrm{KH}$. Asep Abdurrahman Hambali merupakan komunikator yang handal, Sebagian besar waktu yang terpakai untuk kerja kepemimpinan adalah berkomunikasi, baik internal maupun eksternal. Komunikasi yang dilakukan dengan bawahannya bersifat memotivasi agar para bawahan dan santri-santri Pondok Pesantren Al-Mardhiyatul Islamiyah lebih semangat dalam menjalankan kehidupan dan menjadikan pribadi menjadi lebih baik lagi. Komunikasi sangat dibutuhkan dalam kehidupan sehari-hari, dengan adanya komunikasi yang baik dan terarah maka akan tercapai sebuah kesuksesan entah itu dalam hal pekerjaan maupun pergaulan. Menurut Anton Athoilah, Proses komunikasi merupakan timbal balik anatara komunikator sebagai pengirim dan komunikan sebagai penerima pesan, dan yang menciptakan pengertian dan penerimaan yang sama, serta menghasilkan suatu tindakan yang sama untuk mencapai tujuan (Anton Athoilah, 2010:217).

Adapun mengenai keterampilan kepemimpinan, KH. Asep Abdurrahman Hambali memiliki keterampilan kepemimpinan dalam memimpin Pondok Pesantren Al-Mardhiyatul Islamiyah. Dalam dunia pendidikan, Seperangkat keterampilan kepemimpinan harus dimiliki oleh pemimmpin dalam melaksanakan sejumlah tugas. Adapun seperangkat keterampilan kepemimpinan itu adalah keterampilan teknis, keterampilan hubungan manusiawi, dan keterampilan konseptual. Namun, ketiga keterampilan kepemimpinan tersebut tidak semuanya dimiliki oleh $\mathrm{KH}$. Asep Abdurrahman Hambali. Pimpinan Pondok Pesantren Al-Mardhiyatul Islamiyah tidak memiliki 
keterampilan teknis, hal tersebut yang menjadikan pimpinan Pondok Pesantren Al-Mardhiyatul Islamiyah kurang ideal dalam pelaksanaan kepemimpinannya. Menurut Vietzal Rivai, keterampilan teknis merupakan kemampuan menggunakan pemahaman, metode, teknik, dan peralatan yang dipergunakan untuk melaksanakan tugas serta pengalaman dan pelatihan yang diperolehnya (Muslihah, 2012: 64). Keterampilan yang dimiliki oleh pemimpin ditujukan kepada upaya mencapai tujuan pendidikan. Dengan keterampilan kepemimpinan tersebut diharapkan pimpinan Pondok Pesantren Al-Mardhiyatul Islamiyah dapat melaksanakan tugas-tugas kepemimpinannya secara efektif dan efisien.

Kurikulum adalah seperangkat atau sistem rencana dan pengaturan mengenai isi dan bahan pembelajaran yang dipedomani dalam aktivitas belajar mengajar. Kurikulum dapat dijadikan patokan dan pedoman dalam aktivitas pembelajaran di pesantren. Kurikulum yang diberlakukan di Pondok Pesantren Al-Mardhiyatul Islamiyah merupakan kurikulum pesantren salaf yang independen tanpa ikut campurnya kurikulum pemerintah.Kurikulum di Pondok Pesantren Al-Mardhiyatul Islamiyahditerapkan melalui kegiatan pengajian (kurikuler) dan kegiatan lainnya diluar pengajian (ekstrakurikuler).

\section{Kondisi Manajemen Pondok Pesantren Al-Mardhiyatul Islamiyah}

Pada masa kepemimpinan K.H. Abdul Qodir Zaelani, banyak sekali perubahan yang signifikan di Pondok Pesantren Al-Mardhiyyatul Islamiyyah baik dalam masalah manajemen, pendidikan, logistik dan fasilitas lainnya. Perkembangan pada masa K.H. Abdul Qodir Zaelani di dukung oleh para haba'ib (habib) yang memberikan saran-saran dan masukan untuk kemajuan pesantrennya. Selain memberikan masukan, mereka juga memberikan bantuan berupa materi untuk pembuatan asrama dan rehabilitasi masjid serta bantuan yang lainnya.

Pada tahun $2011 \mathrm{KH}$. Abdul Qodir dipanggil Allah SWT., maka penerus, pengganti, pengajar utama dan yang mengembangkan kepemimpinan Pondok Pesantren Al-Mardhiyyatul Islamiyyahadalah anak kedua KH. Abdul Qodir, yakni KH. Asep Abdurrahman Hambali, karena anak pertamanya merupakan seorang putri. Hingga sampai sekarangPondok Pesantren Al-Mardhiyyatul Islamiyyah dipimpin oleh $\mathrm{KH}$. Asep Abdurrahman Hambali,dengan harapan agar Pondok Pesantren Al-Mardhiyyatul Islamiyyahtetap menjadi pusat pengajaran Islam, juga berperan dalam bidang dakwah dan menjadi pelopor kegiatan sosial keagamaan masyarakat Cileunyi Kulon.Manajemen pesantren di Pondok Pesantren Al-Mardhiyyatul Islamiyyah bebas dari campur tangan pemerintah, pimpinan Pondok Pesantren Al-Mardhiyyatul Islamiyyah mengelola pesantren dengan caranya sendiri. Untuk menunjang pelaksanaan manajemen pesantren, dibuatlah organisasi santri agar dapat melancarkan kegiatan-kegiatan kepesantrenan. Pihak pengasuh pondok pesantren hanya memberikan saran dan petunjuk untuk kelancaran organisasi santri tersebut.

Pendidik atau pengajar yang ada di Pondok Pesantren Al-Mardiyyatul Islamiyah berjumlah tujuh orang. Tenaga pendidik di Pondok Pesantren AlMardhiyatul Islamiyah keseluruhannya merupakan keluarga atau kerabat yang tidak lain adalah adik-adik dan kakak dari pimpinan Pondok Pesantren Al- 
Mardhiyatul Islamiyah saat ini yang juga merupakan cucu-cucu dari $\mathrm{KH}$. Abdul Djalil selaku pendiri Pondok Pesantren Al-Mardhiyatul Islamiyah.

KEADAAN DAN JUMLAH STAF PENGAJAR

\begin{tabular}{|c|l|c|c|}
\hline No & \multicolumn{1}{|c|}{ Nama pengajar } & Pendidikan & Keterangan \\
\hline 1. & $\begin{array}{l}\text { KH. Asep Abdurrahman } \\
\text { Hambali }\end{array}$ & Pesantren & $\begin{array}{c}\text { Pengajar santri } \\
\text { putra dan putri }\end{array}$ \\
\hline 2. & $\begin{array}{l}\text { Ust. Cecep Abdullah } \\
\text { Syafe'i }\end{array}$ & Pesantren & $\begin{array}{c}\text { Pengajar santri } \\
\text { putra dan putri }\end{array}$ \\
\hline 3. & $\begin{array}{l}\text { Ust. Agus Muhyiddin Al- } \\
\text { Maliki }\end{array}$ & Pesantren & $\begin{array}{c}\text { Pengajar santri } \\
\text { putra }\end{array}$ \\
\hline 4. & Ust. Al-Gozali & Pesantren & $\begin{array}{c}\text { Pengajar santri } \\
\text { putra dan putri }\end{array}$ \\
\hline 5. & $\begin{array}{l}\text { Ustz. Imas } \\
\text { Halimatussa'diyah }\end{array}$ & Pesantren & $\begin{array}{c}\text { Pengajar santri } \\
\text { putri }\end{array}$ \\
\hline 6. & $\begin{array}{l}\text { Ustadzah Nenden Umi } \\
\text { Kulsum }\end{array}$ & Pesantren & $\begin{array}{c}\text { Pengajar santri } \\
\text { putri }\end{array}$ \\
\hline 7. & Ustadzah lim & Pesantren & $\begin{array}{c}\text { Pengajar santri } \\
\text { putri }\end{array}$ \\
\hline
\end{tabular}

\section{SIMPULAN}

Pesantren Al-Mardhiyatul Islamiyah merupakan pesantren salaf yang didirikan oleh $\mathrm{KH}$. Abdul Jalil di Cileunyi tepatnya di kampung Cibagbagan Desa Cileunyi Kulon Kecamatan Cileunyi Kabupaten Bandung pada hari Rabu 1 Januari 1960. Saat ini, pengganti, penerus dan yang mengembangkan kepemimpinan Pondok Pesantren Al-Mardhiyatul Islamiyah dan sekaligus sebagai pengajar utama adalah $\mathrm{KH}$. Asep Abdurrahman Hambali, dengan harapan agar Pondok Pesantren Al-Mardhiyatul Islamiyah menjadi pusat pengajaran Islam, juga berperan dalam bidang dakwah dan menjadi pelopor kegiatan sosial keagamaan masyarakat Cileunyi Kulon. Konsep kepemimpinan di Pondok Pesantren Almardhiyatul Islamiyah yaitu konsep yang mengacu pada wahyu Allah dalam Al Qur'an tentang etos dan sifat kepemimpinan nabi dan rasul, dikenal dengan konsep profetik. Manajemen pesantren di Pondok Pesantren Al-Mardhiyyatul Islamiyyah bebas dari campur tangan pemerintah, pimpinan Pondok Pesantren Al-Mardhiyyatul Islamiyyah mengelola pesantren dengan caranya sendiri. Untuk menunjang pelaksanaan manajemen pesantren, dibuatlah organisasi santri agar dapat melancarkan kegiatan-kegiatan kepesantrenan. Pihak pengasuh pondok pesantren hanya memberikan saran dan petunjuk untuk kelancaran organisasi santri tersebut.

\section{REFERENSI}

Afifuddin, dkk. (2004). Administrasi Pendidikan. Bandung: Insan mandiri. 
Afifuddin. \& Sutikno, Sobry. (2008). Pengelolaan Pendidikan.Bandung: Prospect.

Athoillah, Anton. (2010). Dasar-DasarManajemen. Bandung: Pustaka Setia.

Badrudin. (2014). Manajemen Peserta Didik. Jakarta: PT Indek.

Burhanudin, dkk. (2003). Manajemen Pendidikan. Malang: Universitas Negeri Malang.

Danim, Sudarwan. (2010). KepemimpinanPendidikan. Bandung: Alfabeta.

Dhofier, Zamakhsyari. (2011). Tradisi Pesantren; Edisi Revisi. Jakarta: LP3ES. Anggota Ikapi.

Djamaluddin. \& Ali, Abdullah. (1998). Kapita Selekta Pendidikan Islam. Jakarta: CV Pustaka Setia.

Haedari, Amin. (2005). Masa Depan Pesantren dalamTtantangan Modernitas dan

Tantangan Kompleksitas Global. Jakarta: IRD Press.

Hasibuan, Malayu S.P. (2006). Manajemen; Dasar, Pengertian dan Masalah. Bandung: PT. Bumi Aksara.

Noor, Mahpuddin. (2005). Potret Dunia Pesantren. Bandung: Humaniora.

Ramayulis. (2011). IImu Pendidikan Islam. Jakarta: Kalam Mulia.

Rusmini, Gaya Kepemimpinan Kiyai Lukman Al-Karim dalam Pengembangan Lembaga Pendidan Islam.

https://media.neliti.com/media/publications/58174-ID-gaya-kepemimpinan-kyailukman-al-karim-d.pdf

Saefullah, dkk. (2012). Manajemen Pendidikan Islam. Bandung: CV Pustaka Setia.

Tatang. (2012). IImu Pendidikan. Bandung: CV. Pustaka Setia.

Tim Dosen Adpen UPI. (2013). Manajemen Pendidikan. Bandung: ALFABETA.

UU No 20 tahun 2003 tentang Sisdiknas, PP No 19 Tahun 2007 tentang standar pengelolaan pendidikan.

https://fauziannor.files.wordpress.com/2013/03/pola-baru-kepemimpinan-kyaidalam-pengembangan-pendidikan-studi-kasus-pondok-pesantrenhidayatullah-surabaya.pdf 